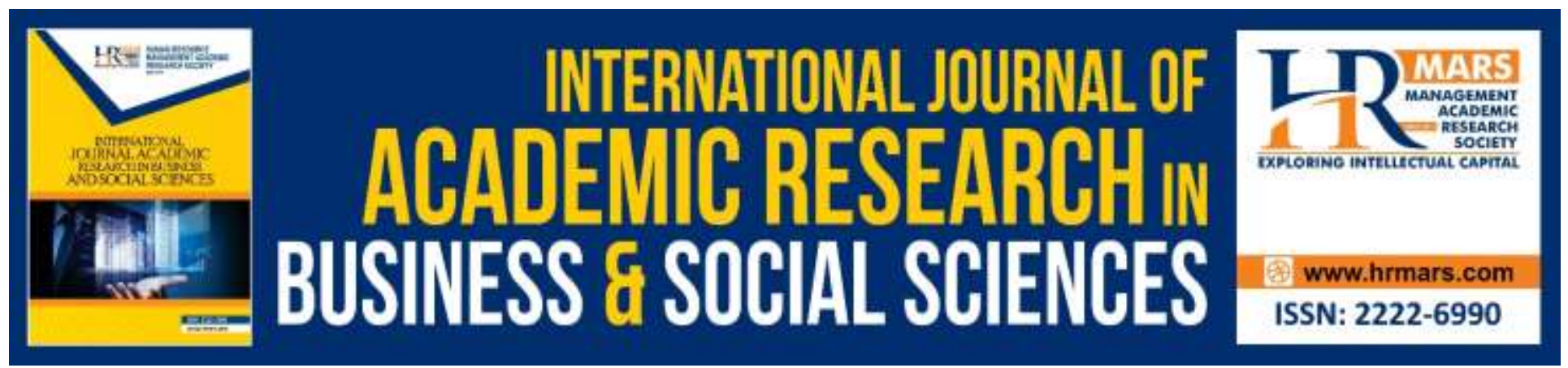

\title{
Application Reading Module for Children with Disabiliy among Students with Non-Verbal Autism
}

Noratiqah Satari, Mohd Hanafi Mohd Yasin, Hasnah Toran, Suziyani Mohamed

To Link this Article: http://dx.doi.org/10.6007/IJARBSS/v10-i3/7083

DOI:10.6007/IJARBSS/v10-i3/7083

Received: 01 February 2020, Revised: 22 February 2020, Accepted: 12 March 2020

Published Online: 28 March 2020

In-Text Citation: (Satari et al., 2020)

To Cite this Article: Satari, N., Yasin, M. H. M., Toran, H., \& Mohamed, S. (2020). Application Reading Module for Children with Disabiliy among Students with Non-Verbal Autism. International Journal of Academic Research in Business and Social Sciences, 10(3), 688-698.

\section{Copyright: (C) 2020 The Author(s)}

Published by Human Resource Management Academic Research Society (www.hrmars.com)

This article is published under the Creative Commons Attribution (CC BY 4.0) license. Anyone may reproduce, distribute, translate and create derivative works of this article (for both commercial and non-commercial purposes), subject to full attribution to the original publication and authors. The full terms of this license may be seen

at: http://creativecommons.org/licences/by/4.0/legalcode

\section{Vol. 10, No. 3, 2020, Pg. 688 - 697}

Full Terms \& Conditions of access and use can be found at http://hrmars.com/index.php/pages/detail/publication-ethics 


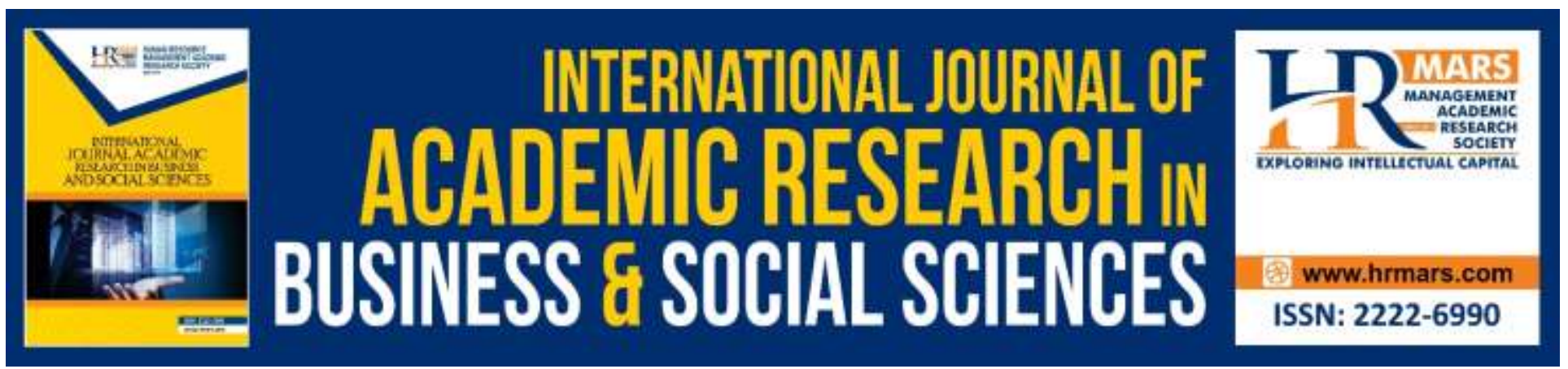

\title{
Application Reading Module for Children with Disabiliy among Students with Non-Verbal Autism
}

\author{
Noratiqah Satari, Mohd Hanafi Mohd Yasin, Hasnah Toran, Suziyani \\ Mohamed \\ Universiti Pendiidkan Sultan Idris, Universiti Kebangsaan Malaysia
}

\begin{abstract}
Autism is one of the categories of those who have a risk of reading problems. This study aims to find out the improvement of Malay language basic reading skills using Reading Module for Children with Disability for three students with non-verbal Autism using single-subject design. Subjects who received intervention at a learning centre for children with Autism The reading module is applied using a phonic and sight words method. The intervention was provided 25 sessions, every day. The teaching strategies in this module are errorless learning and scaffolding. There are three (3) practices provided for each sub-unit and flash cards in this module. In the early stage, all subjects are nonverbal and were not yet master the Malay language reading skills. These single-subject design cases illustrate that reading skill interventions may be effective for early intervention, no behavior problems and verbal Autism and warrant further testing.
\end{abstract}

Keywords: Reading; Autism, Malay language.

\section{Introduction}

Children who suffer from Autism can be identified as early as the age of one year six months and they require early intervention as early as possible (Katheleen, 2011). Early intervention is intended to facilitate students to master basic skills through specific teaching resources that are appropriate to the students' needs. Early intervention can improve the skills deficit experienced by students with Autism (Karanth, and Chandhok 2013). Most reading problems can be avoided or reduced through early intervention programs (Rahil, Sharifah, Roslan and Habibah, 2009).

Reading skills allow an individual and the society to develop well, no matter where they are (Boily, Ouellet and Turcotte, 2015). Reading skills are fundamental to decision making concerning certain things, personal strengths and personal involvement in the surrounding society as well as at the global or international level (Stromquist, 2005). Pre-school students who master the reading skills will exhibit good academic achievements from primary school up to secondary school (Green, Terry and Gallagher 2013). Moreover, the difference between students who have good reading skills and 
those who do not can be seen through achievements in school (Morgan, Farkas and Hibel 2008). Students who have poor reading achievements will continue to be left behind throughout their school years (Moats and Foorman, 2008). Students who have poor reading skills in standard one will probably have poor reading skills when they are in standard four. While students who are identified to have poor reading skills in standard four will remain to be at the poor level when they are in secondary school (Mclaughlin, Speirs and Shenassa, 2014).

Autism is a lifelong disability affecting the social, communication and behavioural as well as causing difficulties in academic and skills mastery (Debra Costley, Trevor Clark 2014). All students with Autism have different characters (Kimberly 2010) and the reading development of students with Autism is also varied (Nation, Clarke, Wright and William 2006). Students with autism have low scores of vocabulary and some of them do have the same or higher scores than typical students (Lindgren, Folstein, Tomblin and Tager-Flusberg 2009). Students with Autism generally have problems to interpret words and understand reading (Asberg, Dahlgren and Dahlgren 2008). Students with Autism require early treatment including education and require teaching aids that are appropriate for the problems they face.

Reading skills are very important to all individuals, including special needs children, because these skills are the channel for assessment and learning in education, and also to increase the opportunities for vocational, self-development, and stimulating a self-reliant life (Light and KentWalsh 2003). The identification and early intervention concerning the literacy should be carried out as early as possible to avoid the occurrence of worst reading skills problems (Ehri and Nunes, 2002).

\section{Objective of the Study}

This study aims to find out the improvement in reading skills using reading module for children with disability. In Malaysian market, there are various Malay language reading modules such as Siri Bacalah Anakku, Modul Express I, Siri Fonik Ria and many others. These modules only focusing on children aged between four to seven years and having reading problems (Nik Eliani and Othman 1997). This study focuses on the application of reading module for children with disability among students with Autism.

\section{Literature Review}

\section{Malay Language Reading Skills}

In Malaysia, Malay language is the national language and is one of the compulsory languages learned by all students in Malaysia (Abdul Rasid 2011). The Malay language uses alphabets with syllables structure. Roman is the writing system and is based on Latin script, which comprises 26 letters that are similar to letters in the English language. A grapheme is a representation of phoneme letters (Rey, Ziegler and Jacobs 2000) used in the Malay language. A grapheme is not only referring to a letter but also a combination of various letters such as digraph and diphthong that represent the phoneme and is the basic unit in a speech or oral language. Overall, Malay language orthography has 34 graphemes: 26 letters, five (5) digraphs (gh, kh, ng, ny and sy) and three (3) diphthongs (ai, au and oi) (Lee and Wheldall 2011). 
Malay language is an agglutinative language in which the addition of morpheme such as the addition to prefixes, suffixes, and the middle of root words can change the meaning of a sentence. For example, ' makan ' (eat) is a verb, when added with a suffix '-an ', it becomes ' makanan ' (food). Malay language has a simpler orthography compared to English language. Grapheme-phoneme of the Malay language is more similar compared to the English language. For example, the Malay word ' malam ' consists of five (5) letters (i.e. ' $m$ ' + ' a ' + ' l' + ' a ' + ' $m$ ') and five (5) phonemes (i.e. /m/ $+/ \mathrm{a} /+/ \mathrm{l} / \mathrm{a} / \mathrm{a} / \mathrm{m} / \mathrm{)}$. On the other hand, the English word has five (5) letters (' $\mathrm{n}$ ' + ' $\mathrm{i}$ ' + ' $\mathrm{g}$ ' + ' $\mathrm{h}$ ' + ' $\mathrm{t}$ ') but only three (3) phonemes (/n/ + /al/ + /t/) (Lee, Low and Mohamed 2013).

\section{Students with Autism and Reading Skills}

Autism has social and interaction as well as repetition of interests and behaviour deficits. However, there is a diversity of spectrum in every child with Autism. $40 \%$ of children with Autism have comorbid with 1) epilepsy; 2) neuropsychiatric symptoms such as depression, anxiety, obsession and phobia; 3) Attention Deficit Hyperactivity Disorder (ADHD); 4) Tourette Syndrome (Gabis and Pomeroy 2014); and 5) speaking problems (Bennett et al. 2014).

The ability to read is very important and it is estimated that individuals with $90 \%$ of speaking disability (such as Cerebral Palsy, Down Syndrome, Autism) have difficulties in reading skills (Foley and Wolter 2010). Nation et al. (2006) conducted a study on decoding, understanding and language skills for children with Autism ( $N=41$ ) aged around 10 years. The study found that nine (9) samples do not have reading skills, while $65 \%$ of the remaining 32 samples have a very low reading comprehension based on Neale Analysis of Reading Comprehension, Second Edition (NARA-II).

\section{Reading Module for Children with Disability}

The reading module is developed by a group of researchers at Universiti Kebangsaan Malaysia (UKM). The module is developed based on the strengths and needs of students with Autism. The module is the basis of reading skills, namely K, V, KV, VKV and KVKV. Phonically is among the methods used to teach reading skills. Sprague (2015) pointed out that phonic is related to a method to teach reading skills concerning the sounds of the letters. The method is also known as cracking the code or decoding. Phonic is a learning method of reading skills at an early stage especially in a word recognition skill.

Word decoding skill involves the ability to recognize words quickly and accurately. This skill involves the processes from printed words to the spoken language or speech. Yahya, Aisah and Azmey (2012) has listed out the six (6) steps that are 1) teaching the relationship between sounds and symbols, 2) introducing the sounds of the letters, 3) relating the symbols of the letters with sounds, 4) building syllables, 5) producing sounds of syllable letters without spelling them out and 6) consolidating syllables. 
INTERNATIONAL JOURNAL OF ACADEMIC RESEARCH IN BUSINESS AND SOCIAL SCIENCES

Vol. 10, No. 3, March, 2020, E-ISSN: 2222-6990 C 2020 HRMARS

\section{Methodology of the Study \\ Experimental Design}

This study used an $A B$ single subject design with three students diagnosed Autism and non-verbal. The baseline data were five sessions and intervention data were 25 sessions. Parents of all subjects provided informed consent, while participants provided assent.

Subject 1: Aged 16 years old Diagnosed at the age of 5 years and non-verbal. The subject did not show his interest to mingle with other friends and sometimes show behavioural problem. At age 10 years olds, the subject received intervention at a learning center for children with Autism. Individual Education Program (IEP) was carried out and Malay language reading skills have been made the objective of the IEP upon the agreement of the subject's parents.

Subject 2: Aged 20 years. Diagnosed at the age of 3 years and could understand simple instruction in English and Malay. He using simple sign language such as toilet, eat, car to communicate with others. He attended school education in the United Kingdom for a few years. After the subject's family moved to Malaysia, he received intervention at a learning center for children with Autism. Malay language reading skills have been made the objective of the IEP upon the agreement of the subject's parents during a discussion.

Subject 3: Aged 5 years. Diagnosed at the age of 2 years and could not speak. The subject could only make a "weit" sound and pulled his hands in order to get something. Received his education at a learning centre for children with Autism at the age of 5 years. The subject did not have basic Malay language reading skills that is not able to recognize names and the sounds of the letters. Therefore, these skills have been made the objective of the IEP upon the agreement of the subject's parents.

Baseline: Researchers will show flash cards to the subjects and an observation done by looking at the responses given.

Reading Module for Children with Dlsability: The activities in this module are to produce the sounds of the letters and to circle the letters. The teacher will read together with the subjects before the subjects try to pronounce the sounds of the letters independently. A teaching plan is developed as a guideline for the teacher to give instructions to the subjects. The subjects will be given five (5) seconds to respond to take flash card following the instructions. If the subject able to take the flash card with distractors independently, subject can move to the next units. If the subjects do not respond, the teacher will prompt the subjects to take the right flash card and continue the same units. 
INTERNATIONAL JOURNAL OF ACADEMIC RESEARCH IN BUSINESS AND SOCIAL SCIENCES Vol. 10, No. 3, March, 2020, E-ISSN: 2222-6990 C 2020 HRMARS

Checklist: The instrument used is the observation based on the developed checklist.

The baseline and intervention (reading module applications) data will be recorded to see the improvement of basic reading skills.

\begin{tabular}{|c|c|c|c|}
\hline Unit & Skills & Unit & Skills \\
\hline 1 & Introduction to ' $a^{\prime}$ & 18 & Introduction to ' $k u^{\prime}$ \\
\hline 2 & Introduction to ' $i^{\prime}$ & 19 & 'ka'vs. 'ku' \\
\hline 3 & ' $a^{\prime}$ vs. ' $i$ ' & 20 & 'ki'vs. 'ku' \\
\hline 4 & Introduction to ' $u$ ' & 21 & 'ka'vs. 'ki'vs. 'ku' \\
\hline 5 & ' $a^{\prime}$ vs. ' $u^{\prime}$ & 22 & Introduction to ' $\mathrm{mama}^{\prime}$ \\
\hline 6 & ' $i$ 'vs' $u^{\prime}$ & 23 & Introduction to ' umi ' \\
\hline 7 & ' $a^{\prime}$ vs. ' $i$ 'vs ' $u^{\prime}$ & 24 & Introduction to ' mami ' \\
\hline 8 & Introduction to ' $m a^{\prime}$ & 25 & Introduction to ' $a k i^{\prime}$ \\
\hline 9 & Introduction to ' $\mathrm{mi}^{\prime}$ & 26 & Introduction to ' $a k u^{\prime}$ \\
\hline 10 & 'ma'vs. ' $m i^{\prime}$ & 27 & Introduction to ' $k a k i^{\prime}$ \\
\hline 11 & Introduction to ' $m u^{\prime}$ & 28 & Introduction to ' $k u k u$ ' \\
\hline 12 & 'ma'vs. ' $m u^{\prime}$ & 29 & Introduction to ' $k a k u$ ' \\
\hline 13 & 'mi'vs. 'mu' & 30 & Introduction to ' maka' \\
\hline 14 & 'ma'vs. 'mi'vs. ' $m u^{\prime}$ & 31 & Introduction to ' muka' \\
\hline 15 & Introduction to ' $k a^{\prime}$ & 32 & Introduction to ' kami ' \\
\hline 16 & Introduction to ' $k i^{\prime}$ & 33 & Introduction to ' kamu' \\
\hline 17 & ' $k a^{\prime}$ vs. ' $k i^{\prime}$ & & \\
\hline
\end{tabular}

Table 1. List of reading skill unit based on reading module for children with disability

\section{Baseline Data Collection and Data Analysis}

Researchers carried out all baseline data collection for the three subjects. Baseline data were collected for each subject over a week period prior to intervention. Data were collected during a classroom reading Bahasa Melayu. Single subject design was used in the analysis visual inspection of graphed data.

\section{Findings of the Study}

The case presented in this paper illustrated those three subjects with non-verbal autism and their ability in reading skills. Reading skills of all subjects involved in using reading module for children with disability can be seen in Figure 1 that are baseline and intervention data. 
INTERNATIONAL JOURNAL OF ACADEMIC RESEARCH IN BUSINESS AND SOCIAL SCIENCES Vol. 10, No. 3, March, 2020, E-ISSN: 2222-6990 C 2020 HRMARS

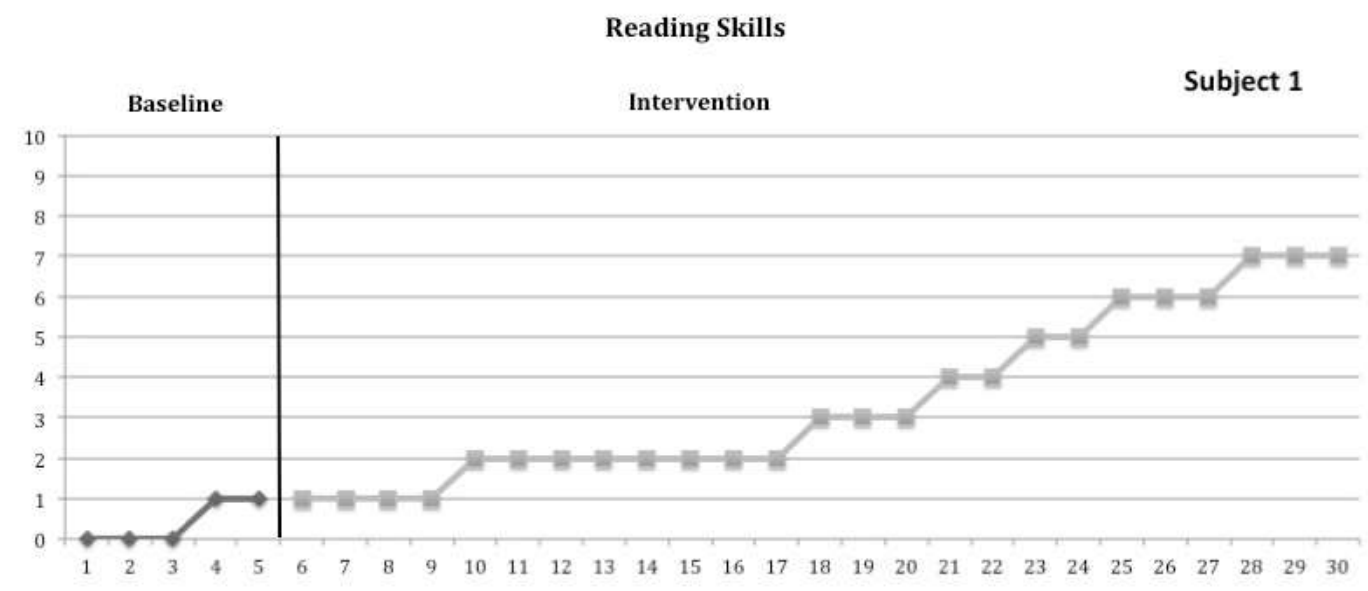

Subject 2

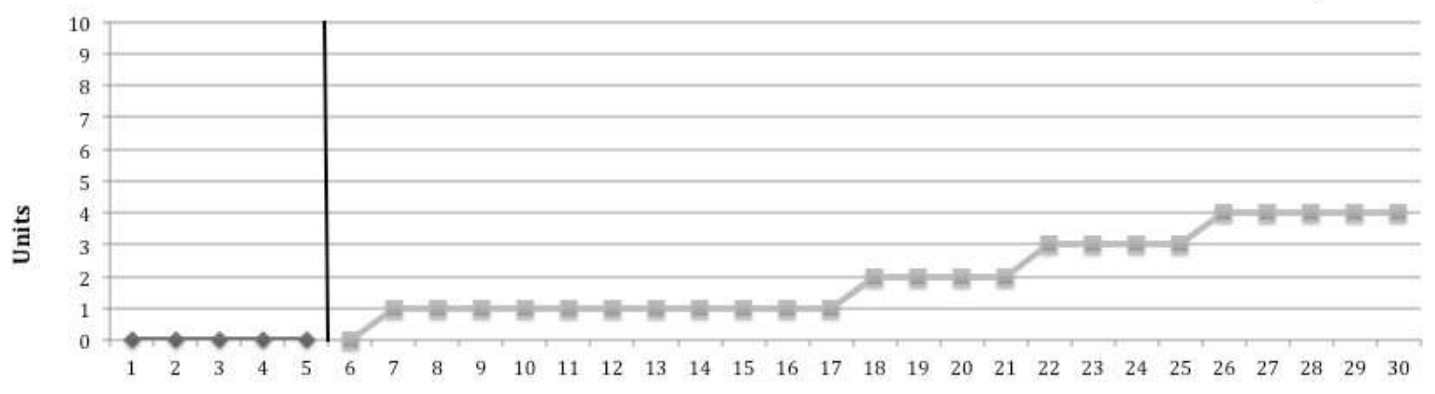

Subject 3

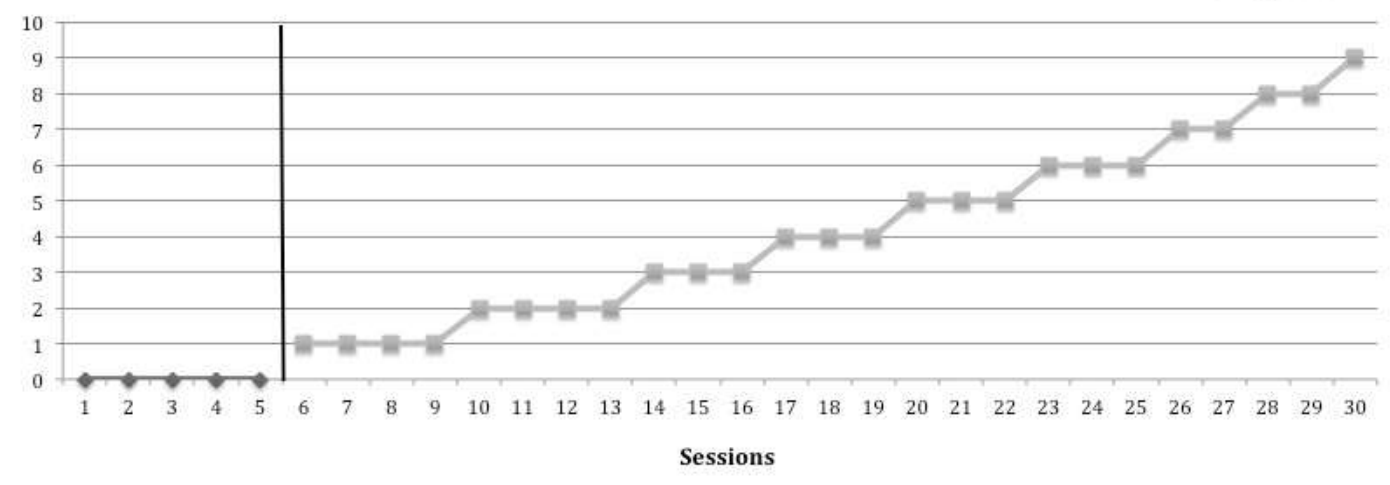

Figure 1: Graphed data units of reading skills over baseline and intervention

Subject 1: The baseline data shows, subject has no basic Bahasa Melayu reading skill. During five sessions, Subject 1 showed knows about "a" in first unit. At the early prior to intervention, subject takes time to move the next unit due to difficult to differentiate between right flash card and distractor. The subject showed improvement and need more prompting from teacher. At the 30 sessions, the subject had ability to recognize the flash card until seven units.

Subject 2: The baseline data shows, subject has no basic Bahasa Melayu reading skill. Subject 2 takes 12 sessions to master one unit and need more physical prompting during the sessions. At the 30 sessions, the subject managed to master 4 units of reading module for children with disability. 
INTERNATIONAL JOURNAL OF ACADEMIC RESEARCH IN BUSINESS AND SOCIAL SCIENCES Vol. 10, No. 3, March, 2020, E-ISSN: 2222-6990 C 2020 HRMARS

Subject 3. The baseline data shows the subject has no basic Bahasa Melayu reading skill. This subject took eight sessions to master two out of 33 units being assessed. The reading skills improvement level of Subject 3 was higher compared to other subjects. At the 30 sessions, the subject achieved until 9 units of reading module for children with disability.

\section{Discussion of the Study}

Students with Autism have a risk of reading difficulties due to the character of the Autism itself especially in terms of communication and social. The different structure of languages (such as morphology, grammar and vocabulary) is among the significant symptoms among students with Autism (Bennett et al. 2008). All subjects have speech problems and the improvement of reading skills is low. Students who experience speech problems have six (6) times difficulties learning reading compared to other typical students (Ritter, Park, Saxon and Colson, 2013). The phonic method is being applied in reading module for children with disability. Many studies have shown that learning to read through phonic will improve students' reading performance at a faster rate (Podhajski, Mather, Nathan and Sammons, 2015). Errorless learning teaching method aims to reduce errors made by students and it is used during learning sessions using reading module for children with disability.. Errorless learning is a factor that improves reading skills of students with Autism. Reading module for children with disability uses a strategy of reading with Autism students in its reading activities to improve the reading skills (Fleury, Miramontez, Hudson and Schwartz, 2014). The scaffolding strategy and repeated reading are also incorporated when using this reading module. Therrian (2004) stated that repeated reading has proven to be effective in improving reading skills among students who have learning difficulties. The scaffolding strategy is an assisted system and a model to stimulate the language development in which the teacher needs to interpret and provide responses based on the students' performance level (Bellon-harn and Harn, 2008). Based on the findings of the study being conducted, this module helps to improve the reading skills of students with non-verbal Autism.

\section{Limitation and Future Research}

Although single-subject designs cannot be generalized, the presented cases illustrate the improvement of the reading skills students with non-verbal autism. Additional limitations of this study include lack of standardized assessment. Future research will involve the students with verbal autism and no behavior problem.

\section{Acknowledgment}

This research was supported by the grant from the Universiti Pendidikan Sultan Idris 2018-0124107-01 (GPU)

\section{Corresponding Author}

Noratiqah Satari, Faculty of Human Development, Universiti Pendidikan Sultan Idris.

Email: atiqahsatari@upsi.edu.my 
INTERNATIONAL JOURNAL OF ACADEMIC RESEARCH IN BUSINESS AND SOCIAL SCIENCES

Vol. 10, No. 3, March, 2020, E-ISSN: 2222-6990 @ 2020 HRMARS

\section{References}

Asberg, J., Dahlgren, S. O., \& Sandberg, D. A. (2008). Basic reading skills in high-functioning Swedish children with autism spectrum disorders or attention disorder. Research in Autism Spectrum Disorders, 2, 95-109.

Jamian, A. R. (2011.) Permasalahan kemahiran membaca dan menulis Bahasa Melayu murid-murid sekolah rendah di luar bandar. Jurnal Pendidikan Bahasa Melayu 1, $1-12$

Bennett, T., Szatmari, P., Bryson, S., Volden, J., Zwaigenbaum, L., Vaccarella, L., Duku, E., \& Boyle, M. (2008). Differentiating Autism and Asperger syndrome on the basis of language delay or impairment. Journal of Autism and Developmental Disorders, 38(4), 616-625

Boily, É., Ouellet, C., \& Turcotte, C. (2015). Effects of an Assisted Repeated Reading Program on Student Fluency in a Large Class in Burkina Faso. Procedia-Social and Behavioral Sciences, 174, 244-250.

Costley, D., Clark, T., \& S. B. (2014). The Autism Spectrum Disorder Evaluative Education Model: A School-Based Method of Assessing and Selecting Interventions for Classroom Use. Received from http://sgo.sagepub.com/content/spsgo/4/4/2158244014556640.full.pdf

Ehri, L. C., \& Nunes, S. R. (2002). The role of phonemic awareness in learning to read. In A. E. Farstrup \& S. J. Samuels (Eds.), What research has to say about reading instruction (pp. 110-139). Newark, DE: International Reading Association.

Fleury, V. P., Miramontez, S. H., Hudson, \& Schwartz, I. S. (2014). Promoting active participation in book reading for preschoolers with Autism Spectrum Disorder: A preliminary study. Child Language Teaching and Therapy, 30(3) 273-288.

Foley, B. E., \& Wolter, J. (2010). Literacy intervention for transition-aged youth: What is and what could be. In D. McNaughton \& D. Beukelman (Eds.), Transition strategies for adolescents and young adults who use AAC (pp. 35-68). Baltimore, MD: Brookes.

Gabis, L. V., \& Pomeroy, J. (2014). An etiologic classification of autism spectrum disorders. Israel Medical Association Journal, 16(5), 295-298.

Green, K. B., Terry, N. P., \& Gallagher, P. a. (2013). Progress in Language and Literacy Skills Among Children With Disabilities in Inclusive Early Reading First Classrooms. Topics in Early Childhood Special Education, 33(4), 249-259.

Lee, L. W., \& Wheldall, K. (2011). Acquisition of Malay word recognition skills: Lessons from lowprogress early readers. Dyslexia, 17(1), 19-37.

Lee, L. W., Low, H. M., \& Mohamed, A. R. (2013). A Comparative Analysis of Word Structures in Malay and English Children's Stories. Social Sciences \& Humanities, 21(1), 67-84.

Light, J. C., \& Kent-Walsh, J. (2003). Fostering emergent literacy for children who require AAC. The ASHA Leader, 8 (10), 29 - 29.

Karanth, P., \& Chandhok, T. S. (2013). Impact of Early Intervention on Children with Autism Spectrum Disorders as Measured by Inclusion and Retention in Mainstream Schools. Indian Journal Pediatric, 80(11), 911-919.

Katheleen, M. M. (2011). Autism from the teacher's perspective. Love. USA.

Kimberly, A. H. (2010). How do I teach this kid to read? Teaching literacy skills to young children autism, from phonics to fluency. Future Horizons. USA. 
INTERNATIONAL JOURNAL OF ACADEMIC RESEARCH IN BUSINESS AND SOCIAL SCIENCES

Vol. 10, No. 3, March, 2020, E-ISSN: 2222-6990 @ 2020 HRMARS

Mclaughlin, M. J., Speirs, K. E. \& Shenassa, E. D. (2014.) Reading Disability and Adult Attained Education and Income: Evidence From a 30-Year Longitudinal Study of a Population-Based Sample. Journal of Learning Disabilities, 47 (4), 374-386

Moats, L. C., \& Foorman, B. R. (2008). Literacy achievement in the primary grades in high-poverty schools. In S. B. Neuman (Ed.), Educating the other America: Top experts tackle poverty, literacy, and achievement in our schools (pp. 91-111). Baltimore, MD: Brookes

Morgan, P. L., Farkas, G., \& Hibel, J. (2008). Matthew effects for whom? Learning Disability Quarterly, 31, 187-198.

Mundy, P., Mastergeorge, A. M., \& Mclntyre, N. S. (2012). Effects of autism on social learning and social attention. In P. Mundy \& A. M. Mastergeorge (Eds.), Educational interventions for students with autism (pp. 3-33). San Francisco, CA: Jossey-Bass.

Nation, K., Clarke, P., Wright, B., \& Williams, C. (2006). Patterns of reading ability in children with autism spectrum disorder. Journal of Autism and Developmental Disorders, 36, 911 - 919.

Nawi, N. N. E., \& Ahamad, O. (1997). Siri cepat bacalah anakku. One stop computer and language consultancy. Malaysia

Podhajski, B., Mather, N., Nathan, J., \& Sammons, J. (2015). Professional development in scientifically based reading instruction: teacher knowledge and reading outcomes. Journal of learning disabilities, 42(5), 403-417.

Satari, N., Yasin, M. H. M., Toran, H., \& Mohamed, S. (2020). Application Reading Module for Children with Disabiliy among Students with Non-Verbal Autism. International Journal of Academic Research in Business and Social Sciences, 10(3), 242-251.

Sprague, C. (2015). Phonics. Research Starters Education, 1 - 7.

Stromquist, N. (2005). The political benefits of adult literacy. Reference document for the EFA Global Monitoring Report 2006.

Satari, N., Yasin, M. H. M., Toran, H., \& Mohamed, S. (2020). Application Reading Module for Children with Disabiliy among Students with Non-Verbal Autism. International Journal of Academic Research in Business and Social Sciences, 10(3), 242-251. 